\title{
Myc/Mycn-mediated glycolysis enhances mouse spermatogonial stem cell self-renewal
}

\author{
Mito Kanatsu-Shinohara, ${ }^{1,2,6}$ Takashi Tanaka, ${ }^{1,6}$ Narumi Ogonuki, ${ }^{3}$ Atsuo Ogura, ${ }^{3}$ Hiroko Morimoto, ${ }^{1}$ \\ Pei Feng Cheng, ${ }^{4}$ Robert N. Eisenman, ${ }^{4}$ Andreas Trumpp, ${ }^{5}$ and Takashi Shinohara ${ }^{1}$ \\ ${ }^{1}$ Department of Molecular Genetics, Graduate School of Medicine, Kyoto University, Kyoto 606-8501, Japan; ${ }^{2}$ Precursory Research \\ for Embryonic Science and Technology (PRESTO), Japan Science and Technology Agency, Kyoto 606-8501, Japan; ${ }^{3}$ Bioresource \\ Center, RIKEN, Tsukuba 305-0074, Japan; ${ }^{4}$ Division of Basic Sciences, Fred Hutchinson Cancer Research Center, Seattle, \\ Washington 98109, USA; ${ }^{5}$ Division of Stem Cells and Cancer, Deutsches Krebsforshungszentrum (DKFZ), 69120 Heidelberg, \\ Germany
}

\begin{abstract}
Myc plays critical roles in the self-renewal division of various stem cell types. In spermatogonial stem cells (SSCs), Myc controls SSC fate decisions because Myc overexpression induces enhanced self-renewal division, while depletion of $M a x$, a $M y c$-binding partner, leads to meiotic induction. However, the mechanism by which $M y c$ acts on SSC fate is unclear. Here we demonstrate a critical link between $M y c / M y c n$ gene activity and glycolysis in SSC selfrenewal. In SSCs, Myc/Mycn are regulated by Foxo1, whose deficiency impairs SSC self-renewal. Myc/Mycn-deficient SSCs not only undergo limited self-renewal division but also display diminished glycolytic activity. While inhibition of glycolysis decreased SSC activity, chemical stimulation of glycolysis or transfection of active Akt1 or Pdpk1 (phosphoinositide-dependent protein kinase 1 ) augmented self-renewal division, and long-term SSC cultures were derived from a nonpermissive strain that showed limited self-renewal division. These results suggested that $M y c-m e d i a t e d$ glycolysis is an important factor that increases the frequency of SSC self-renewal division.
\end{abstract}

[Keywords: glycolysis; Myc; self-renewal; spermatogenesis; spermatogonial stem cells]

Supplemental material is available for this article.

Received August 30, 2016; revised version accepted November 21, 2016.

Stem cells have a unique ability to undergo self-renewal division to reproduce themselves and produce committed progenitors. Analysis of stem cells is generally difficult due to their small number and a lack of specific markers to prospectively isolate this population. Moreover, stem cells in different tissues exhibit strikingly different patterns of self-renewal. For example, hematopoietic stem cells (HSCs) are mitotically dormant and undergo asymmetric division only several times during their life to produce progenitors, which divide more rapidly (Wilson et al. 2008). Neural stem cells (NSCs) undergo asymmetric division and are quiescent (Codega et al. 2014). Stem cells in these tissues rarely divide to form colonies in vitro. In contrast, intestinal stem cells undergo asymmetric division but are constantly dividing (Clevers 2013). Unlike postnatal stem cells, embryonic stem (ES) cells proliferate more rapidly and undergo self-renewal division indefinitely (Martello and Smith 2014). Thus, the mode of self-renewal varies considerably among different tissues, but the mo-

${ }^{6}$ These authors equally contributed to this work.

Corresponding author: tshinoha@virus.kyoto-u.ac.jp

Article is online at http://www.genesdev.org/cgi/doi/10.1101/gad.287045. 116. lecular mechanism underlying this diversity of self-renewal modes is unclear.

Spermatogonial stem cells (SSCs) are distinct from many stem cell types because they do not undergo asymmetric self-renewal division and can dedifferentiate to become ES-like cells (Meistrich and van Beek 1993; de Rooji and Russell 2000; Kanatsu-Shinohara et al. 2004). A single SSC can produce two stem cells (self-renewing division) or two differentiated cells (differentiating division). In the normal seminiferous epithelium, both types of division occur at the same frequency, thereby maintaining a constant SSC population size. SSCs express many pluripotent cell markers, including Pou5f1, Sox2, and Klf4, and convert into ES-like cells by DNA demethylation or suppression of tumor suppressor genes (Takashima et al. 2013). However, they are normally unipotent and undergo slow but constant self-renewal divisions. The genetic and epigenetic properties of SSCs are extremely stable, as

(C) 2016 Kanatsu-Shinohara et al. This article is distributed exclusively by Cold Spring Harbor Laboratory Press for the first six months after the fullissue publication date (see http://genesdev.cshlp.org/site/misc/terms. xhtml). After six months, it is available under a Creative Commons License (Attribution-NonCommercial 4.0 International), as described at http://creativecommons.org/licenses/by-nc/4.0/. 
evidenced by the fact that SSCs cultured for 2 yr maintained normal fertility and exhibited a normal karyotype and androgenetic DNA methylation pattern (KanatsuShinohara and Shinohara 2013). However, much remains unknown about the factors that regulate self-renewal and differentiation of SSCs.

The Myc family of transcription factors plays important roles in the self-renewal division of many stem cell types (Laurenti et al. 2009). For example, Myc controls the balance between self-renewal and differentiation of HSCs by regulating the interaction between HSCs and their microenvironment (Wilson et al. 2004). Only the highly quiescent, dormant HSCs survive the deletion of Mycn and $M y c$ genes, while committed progenitors are lost due to impaired proliferation, differentiation, and apoptosis (Laurenti et al. 2008). In contrast, $M y c / M y c n$ double-knockout NSCs are decreased in number, with slow cell cycling and migration (Way and Knoepfler 2010). A more recent study also showed that $M y c$ depletion induces the proliferation arrest of ES cells (Scognamiglio et al. 2016). Myc-depleted ES cells enter a state of dormancy similar to embryonic diapause. The exact mechanisms by which $M y c / M y c n$ genes influence NSCs or ES cells are not yet clear.

$M y c$ also plays important roles in SSCs. We previously found that $F b x w 7$ ubiquitin ligase deficiency induces active proliferation of SSCs in vitro by increasing MYC expression (Kanatsu-Shinohara et al. 2014). While shRNAmediated $M y c$ depletion decreased colonization of SSCs upon transplantation, $M y c$ overexpression in pup testis culture increased the concentration of SSCs, suggesting that $M y c$ increases the frequency of self-renewal division. A critical role of $M y c$ in SSC differentiation was also reported in a recent study, which showed that Max depletion by shRNA induces meiosis of ES cells and SSCs in vitro (Maeda et al. 2013; Suzuki et al. 2016). However, the analysis of $M y c$ in stem cells is complicated because $M y c$ has many target genes and can act as both a transcriptional activator and repressor (Eilers and Eisenman 2008; Laurenti et al. 2009), and the mechanism by which $M y c$ influences SSC fate remains unknown.

In this study, we examined the molecular mechanism of the role of Myc in SSCs. Use of Myc/Mycn double-knockout SSCs suggested that these genes are involved in the cell cycle machinery and metabolism. Moreover, modulation of SSC metabolism by a chemical compound changed the balance between self-renewal division and differentiation and allowed us to overcome the genetic barrier in the rates of self-renewal division in cultured SSCs. These results suggest that $M y c / M y c n$-mediated glycolysis is one of the critical regulators of SSC self-renewal.

\section{Results}

\section{Regulation of MYC/MYCN expression by FOXO1}

We examined the expression of MYC/MYCN in a primitive male germ cell population. Immunostaining with GFRA1 (mainly $\mathrm{A}_{\text {single }}\left[\mathrm{A}_{\mathrm{s}}\right], \mathrm{A}_{\text {paired }}\left[\mathrm{A}_{\mathrm{pr}}\right]$, and some $\mathrm{A}_{\text {aligned }}$ $\left[\mathrm{A}_{\mathrm{al}}\right]$ undifferentiated spermatogonia) showed that $\sim 80 \%-$ $90 \%$ of GFRA $1^{+}$cells express both MYC and MYCN (Fig.

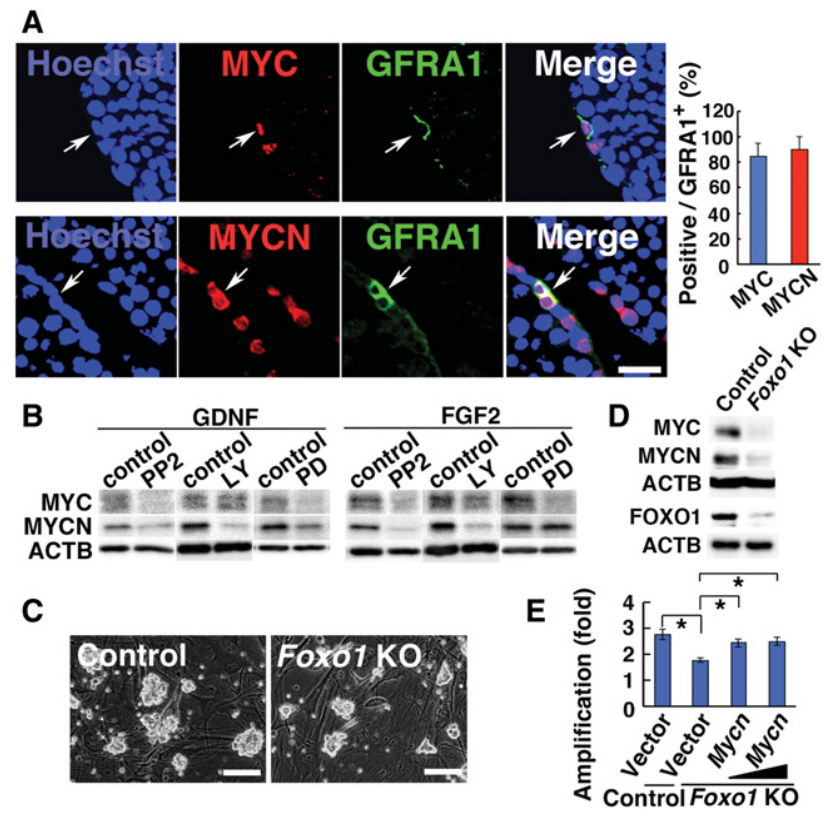

Figure 1. Regulation of MYC/MYCN expression by Foxo1. $(A)$ Double immunohistochemisry of MYC/MYCN with GFRAl in adult testes. Arrows indicate cells expressing both antigens. Cells in 10 tubules were counted for each antigen. $(B)$ Western blot of MYC/MYCN after cytokine stimulation in the presence of chemical inhibitors. Germline stem (GS) cells were cultured without cytokines for $3 \mathrm{~d}$. The indicated cytokines were added $1 \mathrm{~h}$ after the supplementation of indicated inhibitors, and cells were collected $24 \mathrm{~h}$ after cytokine stimulation. (C) Appearance of Foxo1 knockout GS cells showing formation of smaller colonies. $(D)$ Western blot of MYC/MYCN/FOXO1 in Foxo1 knockout GS cells $1 \mathrm{wk}$ after AxCANCre treatment. $(E)$ Rescue of defective proliferation of Foxo1 knockout GS cells by Mycn overexpression. Multiplicity of infection (MOI) $=8$ and 24. $n=4$. Cells were infected simultaneously with AxCANCre and Mycn-expressing lentivirus and passaged on the day after infection. Cell recovery was determined $6 \mathrm{~d}$ after the passage. Bars: $A, 20 \mu \mathrm{m}$; $C, 100 \mu \mathrm{m}$. The asterisk indicates a significant difference.

1A). A similar expression pattern was found for undifferentiated spermatogonia that express $\mathrm{CDH} 1\left(\mathrm{~A}_{\mathrm{s}}, \mathrm{A}_{\mathrm{pr}}\right.$, and $\mathrm{A}_{\mathrm{al}}$ spermatogonia) (Supplemental Fig. S1A). However, MYC expression was lost following differentiation into $\mathrm{KIT}^{+}$differentiating spermatogonia, which predominantly expressed MYCN (Supplemental Fig. S1B). All MYC and MYCN were found in the nucleus. These results suggested that MYC/MYCN expression is regulated differentially in differentiating spermatogonia and that both MYCN and MYC are potentially involved in SSC self-renewal.

To examine the regulation of MYC/MYCN expression, we used germline stem (GS) cells, cultured spermatogonia enriched for SSCs (Kanatsu-Shinohara et al. 2003). FGF2 and GDNF, both of which are SSC self-renewal factors, could induce MYC expression (Supplemental Fig. S1C, D). MYCN was also up-regulated by the same cytokines, albeit to a much lesser degree. We then determined the signaling pathway involved in MYC/MYCN expression in response to self-renewal factor stimulation. GS cells were cultured for $3 \mathrm{~d}$ without cytokines and then treated 
with chemical inhibitors before restimulation with either FGF2 or GDNF. We used inhibitors for SRC, PI3K, and MAP2K1. In SSCs, it is considered that SRC and PI3K activate AKT (Oatley et al. 2007). MAP2K1 is also involved in SSC self-renewal (Lee et al. 2007; Oatley et al. 2007; Ishii et al. 2012).

Western blot analysis revealed that PP2, a SRC family inhibitor, inhibited both MYCN $(P=0.008$ for both GDNF and FGF2) and MYC $(P=0.006$ for GDNF; $P=$ 0.04 for FGF2) expression regardless of the type of stimulation. LY294002, a PI3K inhibitor, significantly suppressed MYCN expression $(P=0.002$ for GDNF; $P=$ 0.003 for FGF2) (Fig. 1B; Supplemental Fig. S1E). Although it effectively suppressed MYC expression after FGF2 stimulation $(P=0.03)$, it did not change MYC expression after GDNF stimulation. In contrast, PD0325901, a MAP2K1 inhibitor, suppressed MYC in both GDNF and FGF2-treated cells $(P=0.0004$ for GDNF; $P=0.002$ for FGF2). It also weakly suppressed MYCN expression by GDNF $(P=$ 0.03 ) but did not influence MYCN after FGF2 supplementation. These results suggested that the PI3K-AKT and MAP2K1 pathways are involved in the regulation of MYCN/MYC expression.

FOXO1 is considered to be the main downstream effector of the PI3K-AKT pathway in SSCs, and Foxo1 knockout mice showed depletion of SSCs and spermatogenesis (Goertz et al. 2011). The MAP2K1 pathway also phosphorylates FOXO1 (Asada et al. 2007). Because FOXO1 has many targets related to SSC self-renewal, we hypothesized that $M y c / M y c n$ are regulated by FOXO1. To test this hypothesis, we derived GS cells from mice homozygous for the floxed Foxo1 allele $\left(F_{\left.O X O 1^{\mathrm{f} / \mathrm{f}}\right)}\right.$ ) (Paik et al. 2007). GS cells were treated with an adenovirus that expresses Cre (AxCANCre) to remove the target gene (Takehashi et al. 2007). As expected, Foxo1 knockout GS cells proliferated poorly after AxCANCre exposure compared with the control cells that had been exposed to a LacZ-expressing adenovirus (Fig. 1C; Supplemental Fig. S2A). Western blot analyses of the AxCANCre-treated GS cells revealed that both MYC and MYCN were significantly down-regulated by Foxo1 deletion (Fig. 1D).

Because these results suggested that MYC/MYCN act downstream from FOXO1 to promote GS cell proliferation, we examined the effect of Mycn overexpression on Foxo1 knockout GS cells. Foxo1 ${ }^{\mathrm{f} / \mathrm{f}}$ GS cells were simultaneously transduced with AxCANCre and a lentivirus that expresses Mycn. Cell counting after $7 \mathrm{~d}$ showed that the proliferative defect of Foxo1 knockout GS cells was successfully rescued by $M y c n$ overexpression $(P=0.01)$ (Fig. $1 E)$, whereas empty vector transfection did not improve the proliferative defect, and cells proliferated significantly more slowly than control cells $(P=0.004)$. These results suggested that $M y c / M y c n$ are critical targets of FOXO1.

\section{Reduced self-renewal division of Myc double-knockout testis cells}

We reported previously that $M y c / M y c n$ overexpression increases the SSC activity of fresh testis cells (Kanatsu-Shinohara et al. 2014). To evaluate the function of $\mathrm{Myc} /$
Mycn, we produced conditional knockout mice with floxed alleles for $M y c$ or $M y c n\left(M y c^{\mathrm{f} / \mathrm{f}}\right.$ or $\left.M y c n^{\mathrm{f} / \mathrm{f}}\right)$. However, our preliminary analysis failed to reveal apparent abnormalities, possibly due to the redundancy of these genes (data not shown). Therefore, we produced mice with conditional alleles for both $M y c$ and $M y c n\left(M y c^{\mathrm{f} / \mathrm{f}} M y c n^{\mathrm{f} / \mathrm{f}} \mathrm{mice}\right)$. We first examined their SSC activity by spermatogonial transplantation (Fig. 2A; Brinster and Zimmermann 1994). $M y c^{\mathrm{f} / \mathrm{f}} \mathrm{Mycn}^{\mathrm{f} / \mathrm{f}}$ mice were mated with transgenic mice [C57BL/6 Tg14(act-EGFP)OsbY01] (Fig. 2A, green) to introduce a donor cell marker. Testes were recovered from 5- to 10-d-old immature pup testes that contained enriched SSCs. The cells were incubated overnight with AxCANCre to produce SSCs without Myc and Mycn genes (Myc double knockout). The cells were then microinjected into the seminiferous tubules of congenitally infertile WBB6F1-W/Wv $(\mathrm{W})$ recipient mice.

Two months after transplantation, recipient mice were euthanized, and their testes were analyzed under UV light (Fig. 2B). The numbers of colonies generated by mutant and control testis cells were 0.8 and 1.2 per $10^{5}$ transplanted cells, respectively (Fig. 2C). Although the value was slightly smaller for Myc double-knockout cells, the difference was not statistically significant. Using the primary recipient testes, we then carried out serial transplantation to quantify the increase of Myc double-knockout SSCs in vivo. The analysis of colony numbers in secondary

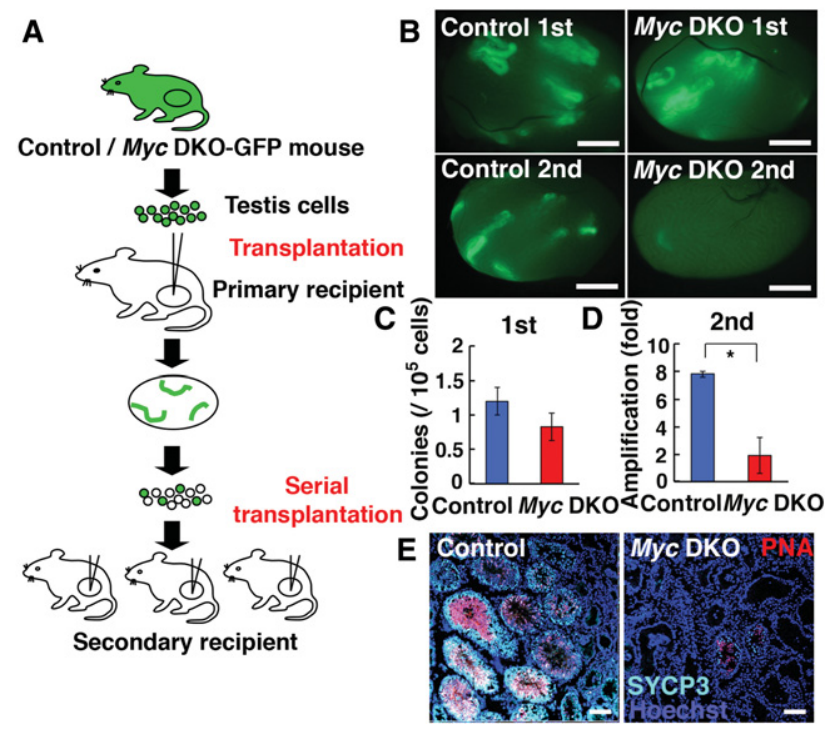

Figure 2. Functional analysis of $M y c$ deficiency in SSCs. (A) Experimental procedure. $(B)$ Macroscopic appearance of primary recipient testis transplanted with $M y c^{\mathrm{f} / \mathrm{f}} M y c n^{\mathrm{f} / \mathrm{f}}$ testis cells after AxCANCre exposure in vitro. Primary recipient testes were dissociated into single cells, which were then transplanted into the secondary recipient testes. $(C)$ Colony counts in primary recipients. $n=12$. (D) Net increase in colony number ([total regenerated colony number $\times 10] /[$ primary colony number used for serial transplantation]). $n=10$. (E) Immunohistochemistry of tubules in primary recipient testis that contains meiotic (SYCP) or haploid (PNA) marker-expressing cells. Bars: $B, 1 \mathrm{~mm}$;, 50 $\mu \mathrm{m}$. The asterisk indicates a significant difference. 
recipients revealed a significant decrease in those of $M y c$ double-knockout testis cells. Assuming (1) that single SSCs produce germ cell colonies and (2) that $10 \%$ of the transplanted SSCs colonize the seminiferous tubules (Nagano et al. 1999; Kanatsu-Shinohara et al. 2006), the numbers of colonies generated by $M y c$ double-knockout and control SSCs were 1.9 and 7.8 per primary colony, an approximately fourfold decrease for $M y c$ double-knockout cells (Fig. 2D). The difference was statistically significant $(P=0.04)$. These results suggested that $M y c$ doubleknockout cells undergo less frequent self-renewal divisions in vivo.

When histological sections were produced to analyze spermatogenesis in recipient testes, we found that recipient testes that received $M y c$ double-knockout testis cells contained fewer tubules with spermatogenesis than those that received control cells. To quantify the degree of differentiation, immunostaining of the recipient testes with meiotic (SYCP3) and post-meiotic (peanut agglutinin; PNA/ markers was performed. Quantification of the tubules revealed that Myc double-knockout testis cells produced significantly fewer tubules with SYCP3 and PNA expression (Fig. 2E; Supplemental Fig. S3). These results suggested that $M y c / M y c n$ genes play important roles in not only SSC self-renewal but also spermatogenic differentiation.

\section{Slow growth of Mycn/Myc double-knockout GS cells}

To evaluate the mechanism of decreased SSC activity in Myc double-knockout testis cells, we derived GS cells from $M y c^{\mathrm{f} / \mathrm{f}} M y c n^{\mathrm{f} / \mathrm{f}}$ mice, which were treated with AxCANCre to delete the target genes (Supplemental Fig. $\mathrm{S} 2 \mathrm{~B})$. As expected from the serial transplantation experiments, Myc double-knockout GS cells proliferated more slowly than control cells (Fig. 3A). While control cells treated with LacZ-expressing adenovirus proliferated $\sim 10^{3}$-fold during $43 \mathrm{~d}$, those with AxCANCre proliferated $\sim 100$-fold during the same period (Fig. 3B). The doubling times for $M y c$ double-knockout and control GS cells were 7.1 and $4.4 \mathrm{~d}$, respectively. Therefore, loss of $M y c$ and $M y c n$ slows but does not abolish GS cell proliferation.

The slow growth phenotype of $M y c$ double-knockout GS cells was successfully rescued by Mycn overexpression $(P=0.002)$ (Fig. 3C; Supplemental Fig. S4), whereas those that received control vector transfection still proliferated significantly slowly $(P=0.01)$. Because $M y c$ can either activate or repress gene transcription depending on its DNAbinding partner, we used two $M y c$ mutants to examine the mechanism underlying the slow growth phenotype. MAX is a major MYC-binding protein. Omomyc, which competes with MAX for binding to MYC but does not prevent MYC-dependent repression of gene expression (Soucek et al. 2002), inhibited $M y c$ double-knockout GS cell proliferation $(P=0.02)$, which suggested that Omomyc suppressed all MYC activities, including gene expression from nontargeted $M y c / M y c n$ alleles or MYCL function. In contrast, Miz1 is another partner that mediates $M y c$ repression of gene expression. MycV394D can activate Ebox-dependent gene activation but does not repress
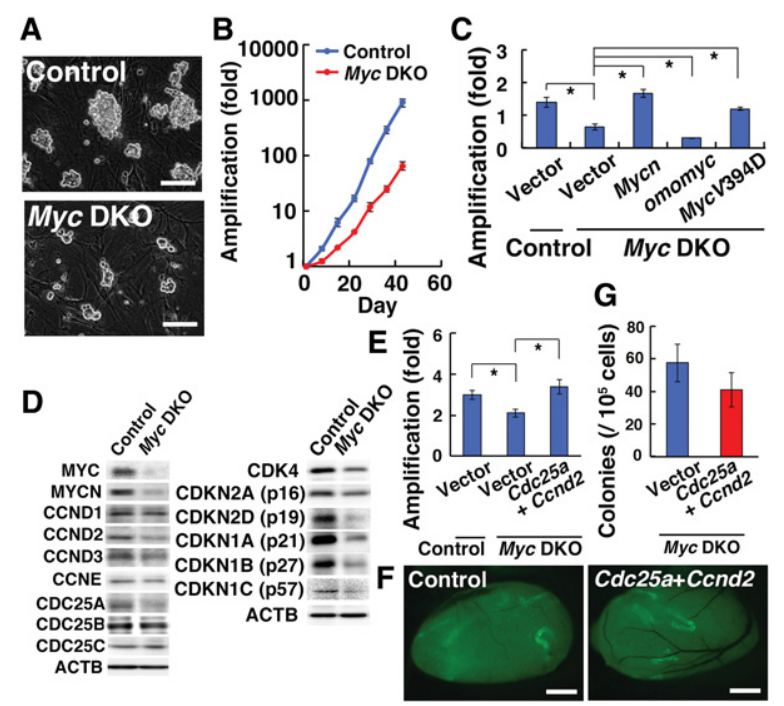

Figure 3. Reduced proliferation of $M y c$ double-knockout GS cells. (A) Appearance of $M y c$ double-knockout GS cells showing formation of smaller colonies. (B) Proliferation of $M y c$ doubleknockout GS cells. $n=3$. Cells were infected with AxCANCre and passaged every $7 \mathrm{~d} .(C)$ Rescue of the proliferative defect of Myc double-knockout GS cells by Myc mutant genes. $n=3$. Cells were simultaneously infected with AxCANCre and the indicated lentivirus and passaged on the day after infection. Cell recovery was determined $7 \mathrm{~d}$ after the passage. $(D)$ Western blot analysis of MYCN and cell cycle-related proteins. The result was confirmed in at least two experiments. $(E)$ Rescue of the proliferative defect of $M y c$ double-knockout GS cells by cotransfection of Ccnd2 and Cdc25a.n=3. (F) Macroscopic appearance of recipient testes that received $M y c$ double-knockout GS cells infected with Ccnd2 and Cdc25a. $(G)$ Colony counts after spermatogonial transplantation. $n=17$. Bars: $A, 100 \mu \mathrm{m} ; F, 1 \mathrm{~mm}$. The asterisk indicates a significant difference.

Miz1-activated transcription (Kerosuo et al. 2008). Because MycV394D expression could restore proliferation $(P=0.006)$, these results suggested that Miz1 is not playing a major role in MYC activity in GS cells. Therefore, defective activation of MYC/MYCN target genes via MAX is responsible for the slow growth phenotype.

We carried out Western blotting to investigate the slow growth phenotype (Fig. 3D). Myc double-knockout GS cells showed significantly reduced expression of CCND2 as well as CCNE1/2 and CDC25A. Because slow growth of $\mathrm{Myc}$ double-knockout GS cells was reminiscent of hypoplasmic spermatogonia in Cdk4 knockout mice (Rane et al. 1999), we assessed CDK4 expression, which was also reduced in Myc double-knockout GS cells. Myc double-knockout GS cells additionally showed a reduction in the levels of several CDK inhibitors, including CDKN1A, CDKN1B, CDKN1C, CDKN2A, and CDKN2D. These results suggested that $M y c$ deficiency causes disturbances in the cell cycle machinery.

We attempted to rescue the cell cycle defects. Because transfection of Ccnd2 and Ccne 1 induces proliferation of GS cells in the absence of cytokines (Lee et al. 2009), we initially transfected these genes into Myc double-knockout 
GS cells. However, transfected cells did not show a rescued slow growth phenotype. Similar experiments using Cdk4 also did not show apparent effects. We then transfected Ccnd2 and Cdc25a into GS cells because Cdc25a positively regulates several CDKs by phosphorylation (Ray and Kiyokawa 2007). While the number of $M y c$ double-knockout GS cells increased by approximately twofold during $5 \mathrm{~d}$, that of $M y c$ double-knockout cells transfected with $C c n d 2$ and $C d c 25 a$ increased by approximately threefold (Fig. 3E). The difference was statistically significant $(P=$ 0.04). However, cells that received empty vector transfection proliferated significantly more slowly than control cells $(P=0.04)$. To examine the effect of $C c n d 2$ and Cdc25a overexpression on SSC activity, we performed spermatogonial transplantation. However, analysis of recipient testes showed that $C c n d 2$ and $C d c 25 a$ cotransfection did not influence SSC activity (Fig. 3F,G).

\section{Defective glycolysis of Myc double-knockout GS cells}

To determine why Myc double-knockout SSCs underwent defective self-renewal division, we focused on the metabolism of GS cells. Because $M y c$ is involved in glycolysis as well as mitochondrial biogenesis (Hsieh et al. 2015), we reasoned that SSCs and progenitors balance these metabolic pathways differently, which might disturb the frequency of self-renewal division. We used a Seahorse extracellular flux analyzer to measure two metabolic parameters: the oxygen consumption rate (OCR) and extracellular acidification rate (ECAR). The OCR measures principally the level of mitochondrial respiration, whereas the ECAR is correlated with glycolytic activity. The maximum mitochondrial respiration, which was measured by the changes of OCR after addition of $\mathrm{p}$ trifluoromethoxyphenylhydrazone (FCCP) followed by anti-mycin and rotenone supplementation, was significantly higher in $M y c$ double-knockout GS cells $(P<$ 0.0001) (Fig. 4A). In contrast, the glycolytic capacity-as indicated by the maximum change in ECAR after addition of glucose, oligomycin, and 2-deoxyglucose (2DG)-was significantly reduced in $\mathrm{Myc}$ double-knockout GS cells $(P<0.0001)$ (Fig. 4B).

Because these results suggested that Myc doubleknockout GS cells depend less on glycolytic activity, we tested the impact of glycolysis on proliferation by culturing GS cells with 2DG, a glucose analog that competes with glucose as a substrate for glycolytic enzymes and acts as an inhibitor of glycolysis. As expected, proliferation of control GS cells was inhibited in a dose-dependent manner $(P=0.04$ for $1.0 \mathrm{mM} ; P=0.001$ for $5.0 \mathrm{mM})$ (Fig. $4 \mathrm{C}, \mathrm{D})$. While the number of control cells increased sevenfold during $6 \mathrm{~d}$, those treated with high-dose 2DG did not increase in number. In contrast, the negative effect of $2 \mathrm{DG}$ on GS cell proliferation was relatively modest in $M y c$ double-knockout GS cells, and suppression was significant only at $5 \mathrm{mM}(P=0.002)$. The suppressive effect of $2 \mathrm{DG}$ was also confirmed for $M y c$ double-knockout GS cells transfected with Cdc25 $a$ and Ccnd2 ( $P=0.007$ for control; $P=0.01$ for Cdc25a and Ccnd2) (Supplemental Fig. S5A). Moreover, transfection of $P d k 1$, the product of which

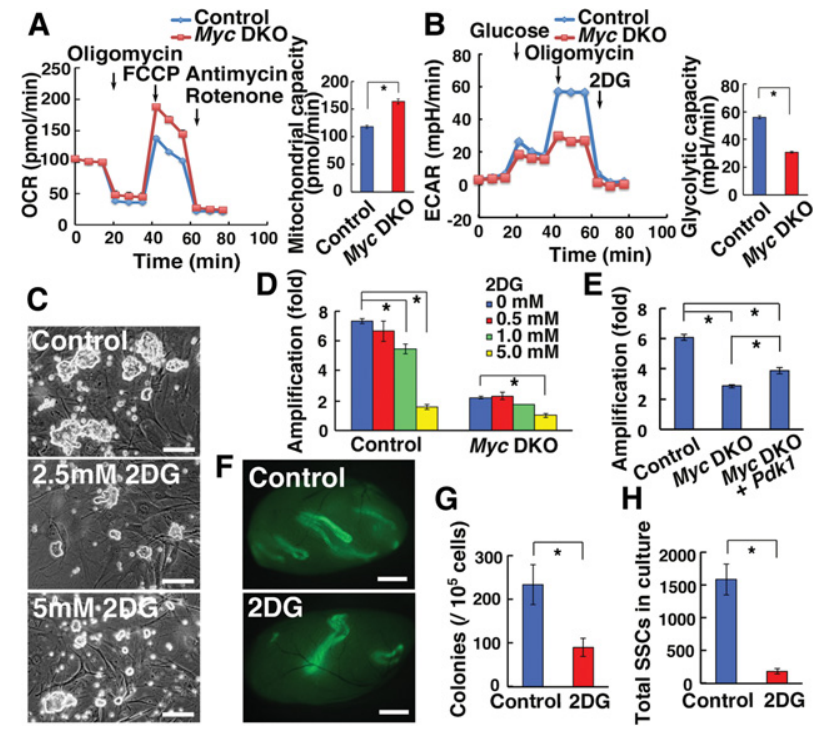

Figure 4. Defective glycolysis in $M y c$ double-knockout GS cells. $(A, B)$ Measurement of the OCR $(A ; n=9)$ and ECAR $(B ; n=9-10)$ of $M y c$ double-knockout GS cells. Analysis was carried out $10 \mathrm{~d}$ $(B)$ and $14 \mathrm{~d}(A)$ after AxCANCre treatment. $(C)$ Appearance of wild-type GS cells cultured with 2DG. $(D)$ Suppression of GS cell proliferation by 2 DG. $n=3$. Cells were simultaneously infected with AxCANCre and passaged on the day after infection. Cell recovery was determined $6 \mathrm{~d}$ after 2DG exposure. $(E)$ Rescue of the proliferative defect of $M y c$ double-knockout GS cells by Pdk1 overexpression. $n=6$. Cells were simultaneously infected with AxCANCre and the indicated lentivirus and passaged on the day after infection. Cell recovery was determined $6 \mathrm{~d}$ after the passage. $(F)$ Macroscopic appearance of recipient testis that underwent transplantation of GS cells cultured for $5 \mathrm{~d}$ with 2DG. $(G)$ Colony counts. $n=12$. $(H)$ Total increase of SSC number. $n=12$. Bars: $C, 100 \mu \mathrm{m} ; F, 1 \mathrm{~mm}$. The asterisk indicates a significant difference.

phosphorylates pyruvate dehydrogenase and reduces the tricarboxylic acid (TCA) activity, improved the proliferation of Myc double-knockout GS cells $(P=0.005)$ (Fig. 4E). Although both $M y c$ double-knockout and rescued cells still proliferated significantly more slowly than control cells $(P=0.001)$, these results suggested that defective glycolysis is one of the factors responsible for the slow growth of Myc double-knockout GS cells.

To examine the effect of glycolytic activity on SSC selfrenewal more directly, we performed spermatogonial transplantation. Green GS cells were cultured in the presence of $5 \mathrm{mM}$ 2DG for $5 \mathrm{~d}$ and transplanted into infertile mice. Analysis of the recipient testes revealed a significant reduction in colony numbers after 2DG treatment (Fig. 4F). The numbers of colonies generated by 2DGtreated and control cells were $90.0 \pm 21.2$ and $233.3 \pm$ 45.3 per $10^{5}$ transplanted cells $(n=12)$, respectively (Fig. $4 \mathrm{G})$, which showed statistical difference $(P=0.009)$. Moreover, while the total number of GS cells increased by 7.8fold over $5 \mathrm{~d}$ in control cultures, that of 2DG-treated cultures increased only 2.1-fold during the same period. Therefore, the total SSC number (SSC concentration $x$ cell increase) was significantly smaller when 2DG was 
added to the culture $(P<0.0001)$ (Fig. $4 \mathrm{H})$. These results showed that suppression of glycolysis reduces the concentration of SSCs in culture and inhibits their self-renewal division.

\section{Derivation of GS cells in a C57BL/6 (B6) background}

The above results suggested that stimulation of glycolysis enhances SSC self-renewal. Indeed, we found that SSC self-renewal factors (GDNF + FGF2) increase the glycolytic capacity by measuring the maximum change in ECAR after addition of glucose, oligomycin, and 2DG $(P<$ 0.0001) (Fig. 5A), while GS cells transfected with Cdc25a and Ccnd2 did not show apparent changes (Supplemental Fig. S5B). Based on these observations, we hypothesized that differences in the levels of glycolytic activity might account for the variation of self-renewal modes in mice with different genetic backgrounds. It has long been known that SSCs in DBA/2 and B6 backgrounds exhibit significant differences in their self-renewal division. SSCs in a DBA/2 background proliferate actively during serial transplantation, and GS cells are readily established from this strain (Kanatsu-Shinohara et al. 2003, 2010). In contrast, although SSCs in a B6 background increase modestly in number following serial transplantation, GS cells cannot be established under

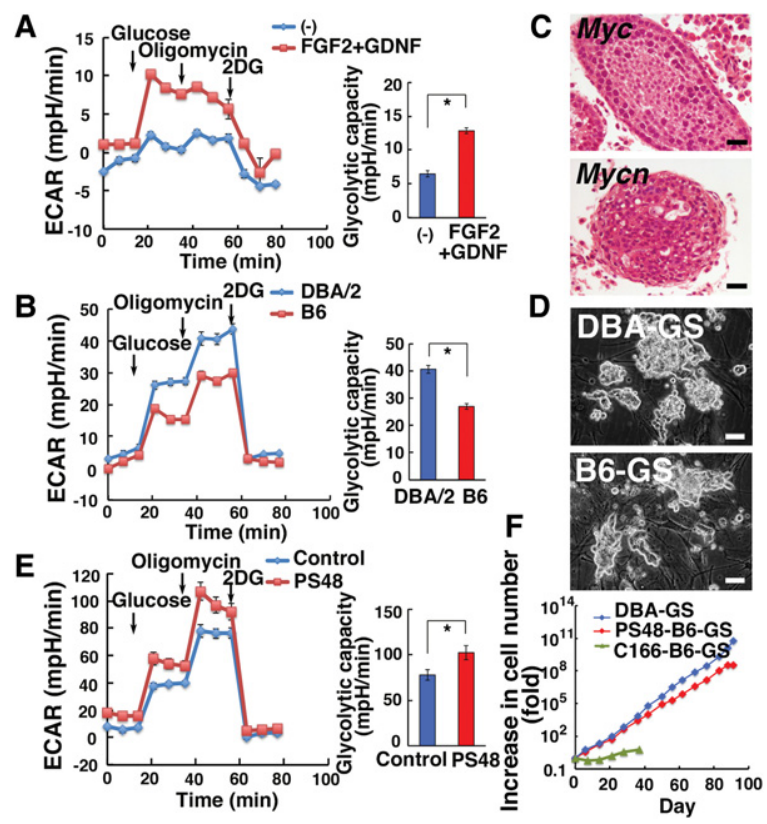

Figure 5. Derivation of GS cells in a B6 background by PS48. (A) ECAR of GS cells cultured with GDNF and FGF2 for 3 d. $n=14$ for control; $n=15$ for FGF2 + GDNF. (B) ECAR of 7-d-old DBA or B6 germ cells cultured with GDNF and FGF2. $n=12$ for DBA; $n=11$ for B6. (C) Germ cell tumors found in recipient testis that underwent transplantation of testis cells overexpressing Myc or Mycn. (D) Appearance of DBA-GS and PS48-B6-GS cells. (E) ECAR of 7to 8-d-old B6 germ cells cultured with GDNF, FGF2, and PS48. $n$ $=14$ for control; $n=13$ for PS48. $(F)$ Proliferation of B6-GS cells. Bars: $C, D, 50 \mu \mathrm{m}$. The asterisk indicates a significant difference. the conventional culture conditions. Although adding GFRA1 reportedly enhanced self-renewal (Kubota et al. 2004), cultured cells could be maintained for only several months, and SSC activity was lost by rapid senescence (Schmidt et al. 2011). Moreover, the batch of the bovine serum albumin (BSA) greatly influences the success of culture, which limits the potential applications of the cells.

To test our hypothesis, we examined the glycolytic capacity of germ cells in immature testes of DBA/2 and B6 mice and found that the glycolytic capacity of DBA/2 germ cells is significantly enhanced $(P<0.0001)$ (Fig. 5B), which supported the notion that enhancement of glycolysis promotes SSC self-renewal. Because of the positive correlation between glycolytic capacity and GS cell derivation, we then attempted to derive GS cells by overexpression of Myc. However, both Myc and Mycn transfectants produced tumors after transplantation, indicating that excessive $M y c$ activity transformed SSCs (Fig. 5C). We therefore searched for culture conditions that augment cytokine-mediated self-renewal division to initiate germ cell colony formation using B6 spermatogonia. By screening chemicals and cytokines, we found that PS48 can reproducibly derive GS cells from a B6 background (B6-GS) (Fig. 5D). Similar cells were also derived by culturing without PS48 on C166 endothelial cells (C166-B6-GS cells), which stimulates proliferation of rabbit spermatogonia (Kubota et al. 2011). However, GS cell colonies did not form when B6 testis cells were cultured on mouse embryonic fibroblasts (MEFs) without PS48. As expected, PS48 stimulated glycolysis of germ cells from B6 pup testes $(P=0.02$; Fig. 5E). Although B6 GS cells derived by either method proliferated for $>1 \mathrm{yr}$, the rate of proliferation was significantly lower for C166-B6-GS cells, and the doubling times of PS48-B6-GS, C166-B6GS, and DBA-GS cells were $3.2,14.2$, and $2.0 \mathrm{~d}$, respectively (Fig. 5F).

\section{Essential role of phosphoinositide-dependent protein kinase 1 (Pdpk1) in SSCs}

Immunocytostaining of cultured cells showed stronger expression of MYC/MYCN in PS48-stimulated cultures $(P=0.0001$ for MYC; $P=0.0003$ for MYCN) (Fig. 6A). This suggested that B6 germ cells do not respond efficiently to self-renewal factors without PS48. PS48 activates Pdpk1. Because PS48 stimulates PDPK1 and thereby induces phosphorylation of AKT at Thr308, we examined the phosphorylation of AKT using Western blotting. As expected, germ cells collected from DBA/2 pup testes showed enhanced phosphorylation for AKT Thr308 $(P=0.003) \quad$ (Fig. 6B; Supplemental Fig. S6A). No significant changes were found for AKT Ser473 and other AKT-related molecules (Fig. 6B; Supplemental Fig. S6A,B).

Because these results suggested poor activation of the AKT pathway in B6-SSCs, we directly evaluated the importance of $P d p k 1$ and $A k t 1$ by transfection experiments. We transfected B6 pup testis cells with constitutively active Pdpk1 and Akt1. Although no colonies were 


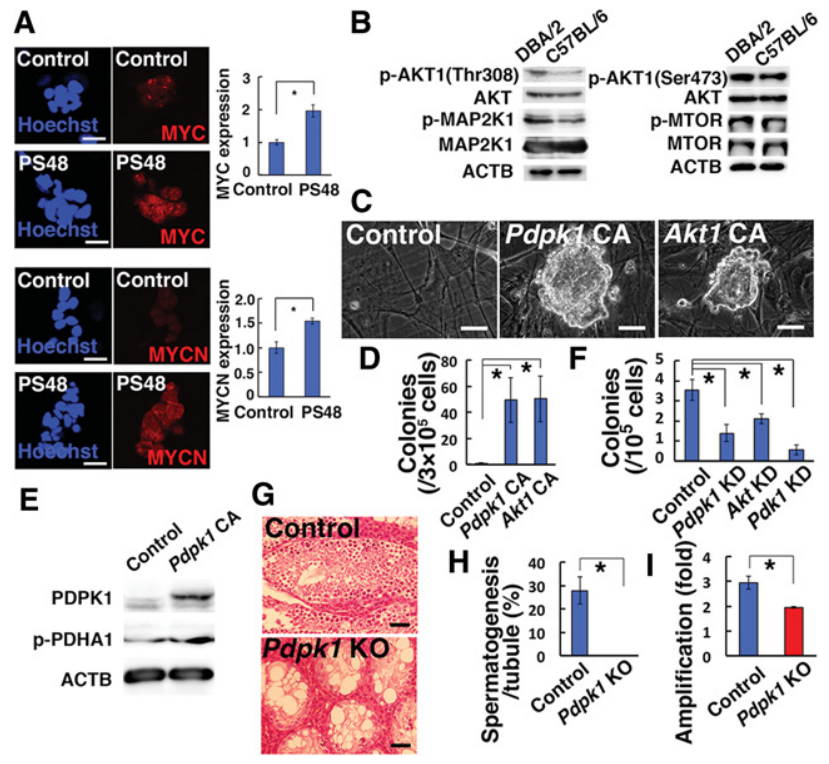

Figure 6. Crucial role of the PDPK1-AKT-PDK1 pathway in SSC self-renewal. (A) Immunostaining of B6-GS cells for MYC ( $n=16$ for PS48; $n=14$ for control) and MYCN ( $n=23$ for PS48; $n=26$ for control) expression. Testis cells from 8 -d-old pups were cultured overnight on gelatin-coated plates and transferred on MEFs for $4 \mathrm{~d}$ before staining with the indicated antibodies. Signal intensity was measured by dividing total signals by colony area. $(B)$ Western blot of 8-d-old DBA/2 and B6 germ cells after overnight culture with GDNF and FGF2. (C) Appearance of B6GS cells established by transfection of constitutively active Pdpk1 (Pdkp1 CA) or Akt1 (Akt1 CA). (D) Quantification of in vitro colony formation by $\mathrm{B} 6$ germ cells after transfection of $P d k p 1$ CA or Akt1 CA. $n=4$. Germ cell clumps were enumerated $37 \mathrm{~d}$ after transfection of $3 \times 10^{5} \mathrm{~B} 6$ germ cells. (E) Western blot of PDHA1 after Pdpk1 CA transfection in B6-GS cells $3 \mathrm{~d}$ after transfection. $(F)$ Colony counts in recipient mouse testes that underwent transplantation of testis cells transfected with lentivirus vectors expressing shRNA against $P d p k 1, A k t$, or $P d k 1 . n=18$ for control; $n=12$ for Pdpk1; $n=13$ for Akt; $n=12$ for Pdk1. $(G)$ Histological appearance of recipient testes transplanted with $P d p k 1^{\mathrm{f} / \mathrm{f}}$ testis cells after exposure to AxCANCre. $(H)$ Quantification of seminiferous tubules with spermatogenesis. At least 354 tubules in four testes were counted. (I) Proliferation of $P d p k 1^{\mathrm{f} / \mathrm{f}}$ GS cells after AxCANCre treatment. Cells were infected with AxCANCre and passaged at $5 \mathrm{~d}$ after infection. Cell recovery was determined $7 \mathrm{~d}$ after the passage. $n=3$. Bars: $A, C, 20 \mu \mathrm{m}$; $G, 50 \mu \mathrm{m}$. The asterisk indicates a significant difference.

generated by transfection of empty vector, GS cell colonies were readily established by $P d p k 1$ or $A k t 1$ overexpression $(P=0.03)$ (Fig. 6C,D). Pdpk1 overexpression increased phosphorylation of PDHA1 (Fig. 6E). To study the function of this pathway, we also carried out knockdown experiments. B6 testis cells were transfected with shRNA against $P d p k 1, A k t 1-3(A k t)$, and $P d k 1$ and transplanted into the seminiferous tubules. All knockdown treatments resulted in significant decreases in colonization $(P=0.006$ for Pdpk1; $P=0.04$ for Akt; $P=0.0001$ for $P d k 1$ ) (Fig. 6F; Supplemental Fig. S7). There were no significant differences among $P d p k 1, A k t$, and $P d k 1$.
To validate our observation, $P d p k 1$ function was examined using conditional knockout mice. Testis cells from $P d p k 1^{\mathrm{f} / \mathrm{f}}$ mice transfected with AxCANCre showed poor colonization in the seminiferous tubules $(P=0.003)$ (Fig. 6G,H; Supplemental Fig. S2C), and GS cells established from $P d p k 1^{\mathrm{f} / \mathrm{f}}$ mice showed significantly reduced proliferative activity after AxCANCre-mediated deletion of Pdpk1 $(P=0.02)$ (Fig. 6I). Taken together, these results suggested that increased AKT activation facilitates GS cell establishment.

\section{Phenotypic and functional analysis of B6-GS cells}

We next compared the phenotypes of PS48-B6-GS cells and DBA-GS cells. Because recovery of C166-B6-GS cells was too low, only PS48-B6-GS cells were used in this experiment. Real-time PCR analysis revealed that expression of Nanos2, Neurog3, Pou5f1, and Etv5 was significantly up-regulated in PS48-B6-GS cells $(P=0.008$ for Nanos2; $P=0.03$ for Neurog3; $P=0.004$ for Pou5f1; $P$ $=0.04$ for Etv5) (Fig. 7A). Moreover, D-type cyclin genes were also expressed more strongly despite their slow growth $(P=0.004$ for Ccnd1; $P=0.005$ for $C c n d 2 ; P<$ 0.0001 for $C c n d 3)$, which may be caused by strain differences in mRNA stability (Butler et al. 2002). Flow cytometric analysis indicated down-regulation of several antigens, including KIT, ITGB1, and CD9 $(P=0.002$ for KIT; $P=0.05$ for ITGB1; $P=0.02$ for CD9) (Fig. 7B). In contrast, GFRA1 was expressed more strongly in PS48-B6-GS

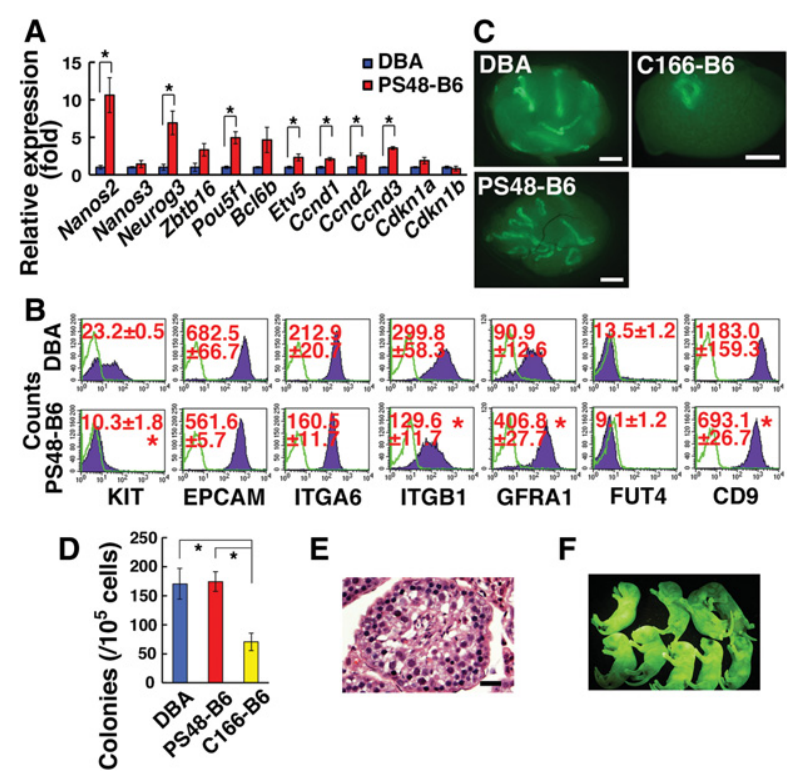

Figure 7. Phenotypic and functional analyses of B6-GS cells. $(A)$ Real-time PCR analysis. $n=3-5$. (B) Flow cytometry. $n=3$. Green lines indicate controls. $(C)$ Macroscopic appearance of recipient testis that underwent transplantation of B6-GS cells. $(D)$ Colony counts. $n=23$ for PS48-B6; $n=22$ for DBA; $n=13$ for C166-B6. (E) Histological appearance of recipient testis transplanted with PS48-B6-GS cells, which were cultured for 238 d. $(F)$ Offspring born from C166-B6-GS cells. Bars: $C, 1 \mathrm{~mm} ; E, 50 \mu \mathrm{m}$. The asterisk indicates a significant difference. 
cells $(P=0.0005)$. While ITGB1 and CD9 are broadly expressed in spermatogonia populations, KIT is expressed in differentiating spermatogonia, and GFRA1 is expressed in $A_{s}, A_{p r}$, and some $A_{a l}$ undifferentiated spermatogonia. Therefore, these phenotypic analyses suggested that PS48-B6-GS cells are more enriched for undifferentiated spermatogonia, possibly including SSCs.

To test this directly, we performed transplantation experiments. PS48-B6-GS and DBA/2-GS cells were cultured on MEFs and transplanted at various time points. We also used C166-B6-GS cells for comparison. The numbers of colonies generated by DBA-GS, PS48-B6-GS, and C166B6-GS cells were $170.0,173.9$, and 70.4 per $10^{5}$ transplanted cells, respectively (Fig. 7C,D), and no difference was found between PS48-B6-GS and DBA-GS cells. However, the number of colonies generated by C166-B6-GS cells was significantly smaller than that generated by the other types of cells $(P=0.01$ for DBA-GS; $P=0.008$ for PS48-B6), suggesting that self-renewal stimulation by $\mathrm{C} 166$ is weaker than that by PS48. Thus, PS48-B6-GS and DBA/ 2-GS cells contain similar amounts of SSCs irrespective of differences in their phenotypes.

\section{Normal offspring born from GS cells in a B6 background}

Because a histological analysis showed normal spermatogenesis (Fig. 7E), we transplanted PS48-B6-GS and C166B6-GS cells 127 and $100 \mathrm{~d}$ after initiation of culture, respectively, to test their fertility. Recipient testes were collected 70 and $103 \mathrm{~d}$ after transplantation. Elongated spermatids were microinjected into oocytes after cryopreservation of recipient testes. A total of 53 and $61 \mathrm{em}-$ bryos were produced for PS48-B6-GS and C166-B6-GS cells, respectively. The next day, 46 embryos that reached the two-cell stage were transferred into the uteri of pseudopregnant mothers. Sixteen and 17 offspring were born, respectively, for PS48-B6-GS and C166-B6-GS cells (Fig. $7 F)$. These results showed that both types of B6-GS cells are competent in producing offspring.

\section{Discussion}

We initiated this study by examining the regulation of Myc genes. As expected from their positive effect on SSCs (Kanatsu-Shinohara et al. 2014), MYC and MYCN were up-regulated by either FGF2 or GDNF. Based on the results from chemical inhibitors, we suspected the involvement of Foxo1, which has been reported to be essential for SSC self-renewal (Goertz et al. 2011). FOXO1 acts downstream from the PI3K-AKT and MAP2K1 pathways and influences many genes related to SSC self-renewal, including Ret, Egr4, and Sall4. We produced Foxo1 knockout GS cells and confirmed their proliferative defect. These cells have reduced MYC and MYCN expression, and the proliferative defect of Foxo1 knockout GS cells could be rescued by Mycn expression (Fig. 1E). Therefore, although FOXO1 has many targets, our results suggested that Myc and Mycn are critical targets of FOXO1 in driving self-renewal.
To understand the function of $M y c / M y c n$, we next produced Myc double-knockout GS cells. Because of the similarity between GS cells and ES cells and recent reports on meiotic induction of Max-depleted ES and GS cells (Maeda et al. 2013; Suzuki et al. 2016), we expected that Myc double-knockout GS cells cease proliferating and enter meiosis. However, Myc double-knockout GS cells maintained proliferation at a significantly reduced rate (Fig. 3B), which is somewhat similar to $M y c$ doubleknockout NSCs (Way and Knoepfler 2010). This phenotype was not limited to in vitro culture conditions because serial transplantation showed significantly reduced selfrenewal division of $M y c$ double-knockout SSCs in seminiferous tubules (Fig. 2D). Although Myc double-knockout GS cells proliferated very slowly, no meiotic cells were evident. On the contrary, the significantly reduced meiotic marker expression in recipient testes suggests that $M y c / M y c n$ are necessary for completing meiosis (Fig. 2E). Therefore, unlike $M y c / M y c n$-deficient ES cells that stop proliferating but maintain their pluripotency (Scognamiglio et al. 2016), a decrease in Myc activity in SSCs not only increases the frequency of differentiating division but also compromises their meiotic capacity despite the similarities of the two cell types.

The decreased proliferation upon $M y c / M y c n$ deficiency can be attributed to the fact that MYC augments expression of genes involved in multiple aspects of cellular growth and proliferation. Several recent studies suggested that $M y c$ functions as a general modulator of widespread gene expression in the cell rather than as a transcription factor with a set of highly specific targets (Lin et al. 2012; Nie et al. 2012). It is probably not an on-off specifier of gene activity but is a nonlinear amplifier of expression. In ES cells, it was reported that MYC binds the core promoter region of a large fraction of actively transcribed genes and functions to enhance transcription elongation (Rahl et al. 2010). Therefore, it is possible that down-regulation of CDK inhibitors may not be sufficient to enhance proliferation of $\mathrm{Myc}$ double-knockout cells whose overall gene activity is likely suppressed.

Although the slow proliferation phenotype of $M y c$ double-knockout cells could be rescued by $C c n d 2$ and $C d c 25 a$ overexpression, the transfected cells did not influence SSC activity (Fig. 3G), which suggested that the speed of division and frequency of self-renewal are not necessarily positively correlated. Because of the possible correlation between "stemness" and metabolism, we analyzed the glycolytic activity of GS cells. The metabolic function of $M y c$ is context-dependent; Myc is implicated in glycolysis but is also involved in mitochondrial biogenesis and oxygen consumption (Hsieh et al. 2015). Therefore, we analyzed the glycolytic activity of GS cells and found that Myc double-knockout GS cells have reduced glycolytic activity (Fig. 4A) and that Pdk1 overexpression could also partially rescue the proliferative defect (Fig. 4E). The mechanism by which PS48 rescues Myc double-knockout GS cells is currently unknown. Because the breakdown of glucose provides the first six-carbon molecule required for the pentose phosphate pathway, we speculate that this change in glycolysis metabolism 
provides resources, including ribose and glycerol for nucleotide, amino acid and lipid biosynthesis, and nicotinamide adenine dinucleotide phosphate for more rapid cell proliferation. Moreover, Myc double-knockout GS cells were significantly less sensitive to 2DG (Fig. 4D). These results suggested that the poor glycolytic phenotype of Myc double-knockout GS cells prevented efficient self-renewal division and reduced their SSC activity. Consistent with this observation, transplantation of GS cells cultured with 2DG showed reduced SSC activity (Fig. $4 G)$, which indicated that glycolysis is a critical regulator of SSC self-renewal.

Although Myc influences stem cells in different tissues, the mechanisms for the stem cell defects largely have remained unclear. In SSCs, our study suggests that the glycolytic defect by $M y c$ deficiency impairs self-renewal. Several studies have suggested the involvement of metabolic factors in self-renewal and differentiation. For example, HSCs are mitotically dormant and use glycolytic metabolism for energy production, while progenitor cells depend more on oxidative phosphorylation (Takubo et al. 2013). Although Myc is involved in HSC self-renewal, Myc regulates cell adhesion in HSCs. In fact, not all stem cells are totally glycolytic because ES cells are bivalent in energy production and switch from glycolysis to mitochondrial respiration on demand (Zhou et al. 2012). In contrast, more differentiated epiblast stem cells are highly glycolytic. However, very little is known about the metabolism of SSCs. Germ cells undergo complex changes in metabolic patterns before maturating into sperm (Rato et al. 2012). While most spermatogenic cells use the TCA cycle preferentially over glycolysis, spermatogonia are supplied with nutrients from blood components and are thought to depend on glucose for ATP production (Rato et al. 2012). Spermatocytes are intermediate and can depend to some extent on glycolysis. Spermatids use the TCA cycle exclusively for energy production, but spermatozoa again retain the ability to use glucose/fructose as the major source of energy. Although the importance of glycolysis in spermatogonia metabolism has been suggested, committed progenitors comprise the great majority of the spermatogonia population. Therefore, it has been difficult to analyze the role of glycolysis in SSCs. Although the exact mechanism of glycolysis dependency of SSC self-renewal is currently unclear, core transcription factors such as POU5F1 regulate glycolytic enzymes in ES cells (Kim et al. 2015). Because of the similarity between GS cells and ES cells, it is possible that a similar relationship exists in SSCs.

Based on these observations, we hypothesized that glycolytic capacity might explain genetic differences in SSC self-renewal. Derivation of GS cells in a B6 background is notoriously difficult (Kanatsu-Shinohara et al. 2003). Its success depends on the batch of BSA (Kubota et al. 2004), and SSC frequency is significantly reduced with enhanced aging (Schmidt et al. 2011; Aoshima et al. 2013). Using B6 mice as a model, we found that PS48 reliably establishes GS cells in a B6 background irrespective of the BSA batch. Although previous studies suggested C166 to be useful for culturing rabbit germ cells (Kubota et al.
2011), it was less effective than PS48, and cells proliferated poorly with lower SSC activity, which suggested that C166 cells secrete as-yet uncharacterized self-renewal factors that enhance glycolysis.

PS48 stimulates PDPK1, which induces AKT phosphorylation at Thr308. However, a previous analysis of Pdpk1 knockout mice showed enhanced SSC activity (Goertz et al. 2011), which was not in agreement with our hypothesis. To resolve this discrepancy, we analyzed Pdpk1 knockout mice and found that the gene is necessary for SSC self-renewal. The impact of Pdpk1 knockout was more severe than $M y c$ double knockout. This is probably because, unlike MYC, PDPK1 is acting directly upstream of multiple signal transduction and growth pathways. At least two factors need to be considered to explain the difference between the two types of knockout mice. First is the method of characterizing SSCs. Although Pdpk1 knockout testes contained ZBTB16 ${ }^{+}$undifferentiated spermatogonia in the previous study, it was not clear whether the increased spermatogonia contained SSCs or committed progenitors. Our functional transplantation assay suggested that $P d p k 1$ is necessary for SSCs. Second is the timing of Pdpk1 deletion. Because the $D d x 4$-Cre transgenic mice used in the previous study started to express the gene $\sim 15.5$ d post-coitum (dpc) (Gallardo et al. 2007), deletion of Pdpk1 during fetal development might have influenced functional maturation of the gonocytes into spermatogonia. The timing of target gene deletion has a considerable impact on the phenotype in SSCs. In fact, Pten knockout SSCs produced by Cre expression under the Alpl promoter, which is expressed in $13.5 \mathrm{dpc}$ gonocytes, proliferated actively and formed teratomas (Kimura et al. 2003), while those produced by $D d \times 4$-Cre disappeared from the seminiferous tubules (Goertz et al. 2011).

GS cells were successfully derived from B6 mice by PS48 or Akt1/Pdpk1 overexpression. Differences in genetic background can significantly influence self-renewal. The most famous example is ES cells /Ohtsuka and Niwa 2015). ES cells in a 129 background are readily established, while those in other strains are refractory to the conventional culture conditions. It was recently found that the difference is caused by the imbalance between JAK-STAT3 and MAPK activities. The former pathway is augmented in ES cells in permissive strains, while the latter pathway is hyperactivated in other strains (Ohtsuka and Niwa 2015). In hematopoiesis, mice in a DBA background contain more HSCs, which proliferate more actively (Muller-Sieburg and Riblet 1996). Latexin or miR$125 a$ is thought to be involved in this enhanced proliferation (Liang et al. 2007; Gerrits et al. 2012). However, the mechanism of their influence on self-renewal division is unknown. Our study suggests that metabolic activity contributes to the genetic difference in self-renewal activity. Although SSCs cultured in previous studies underwent senescence and lost their SSC activity, cells stimulated by PS48 or cultured on C166 maintained SSC activity for at least $6 \mathrm{mo}$, and the BSA batch did not influence the derivation rate. The culture method may be useful in improving protocols for derivation of GS cells in a wide range of animal species. 
At least two questions arise from this study. First, what is the mechanism of suppression of the differentiation of Myc double-knockout GS cells? A recent study showed that ablation of $M a x$, a critical partner for $M y c$, induces spermatogenic differentiation of ES and GS cells in vitro (Maeda et al. 2013; Suzuki et al. 2016). It is considered that Max ablation compromises Myc function and derepresses meiotic genes. On the contrary, our study revealed that differentiation is inhibited in germ cell colonies from Myc/Mycn double-knockout mice. The discrepancy between the two studies needs to be explained. Second, we still do not know the genes responsible for the genetic difference between B6 and DBA/2. Although we tested the effects of Latexin and microRNA cluster 99b/let-7e-125a in promoting SSCs in a B6 background, they did not show positive effects. Identification of target genes will provide valuable information on the regulation of metabolism in SSCs.

Our study revealed multiple roles for $M y c$ in SSC regulation. Myc/Mycn deficiency significantly reduced the proliferation rate of GS cells by down-regulating cell cycle-related genes. Besides their roles in cell cycle regulation, the loss of $\mathrm{Myc} / \mathrm{Mycn}$ also altered the metabolic pattern of GS cells. As previous studies have shown, $M y c / M y c n$ likely play additional roles in SSCs, including apoptosis regulation and tumorigenesis (Morimoto et al. 2012). Thus, the role of Myc/Mycn in SSCs is multifaceted, and modification of their specific function may prove useful for controlling the differentiation and self-renewal division of SSCs. Similar manipulation of Myc downstream molecules might facilitate or inhibit differentiation of SSCs into meiosis. How the extracellular environment influences energy metabolism of SSCs and their relationship with $M y c$ will also be an interesting area for future studies. Our in vitro model will facilitate further investigation of SSC metabolism.

\section{Materials and methods}

\section{Animals}

$\mathrm{Mycn}^{\mathrm{f} / \mathrm{f}}$ and $\mathrm{Myc}^{\mathrm{f} / \mathrm{f}}$ mice were described previously (Knoepfler et al. 2002; Wilson et al. 2004). Pdpk $1^{\mathrm{f} / \mathrm{f}}$ and Foxo $1^{\mathrm{f} / \mathrm{f}}$ mice were generous gifts from Dr. M. Kasuga (Kobe University, Kobe, Japan) and Dr. R. DePinho (Dana-Farber Cancer Institute, MA). In some experiments, we also used green mice (gift from Dr. M. Okabe, Osaka University, Japan) to introduce a donor cell marker. For deletion of target genes in vitro, testis cells were dissociated into single cells by a two-step enzymatic procedure using collagenase and trypsin (Ogawa et al. 1997) and exposed to AxCANCre (RIKEN BRC) at a multiplicity of infection (MOI) of 2.0 (Takehashi et al. 2007). AxCANLacZ was used as a control. After overnight incubation, the virus was removed by replacing the culture medium.

\section{Statistical analysis}

Significant differences between means for single comparisons were determined by Student's $t$-tests. Multiple comparison analyses were carried out using ANOVA followed by Tukey's honestly significant difference test.

\section{Acknowledgments}

We thank Dr. Masato Kasuga, Dr. Wataru Ogawa, and Dr. Tetsuo Noda for the generous gift of $P d p k 1^{\mathrm{f} / \mathrm{f}}$ mice. We also thank Dr. Ronald DePinho for Foxo1 ${ }^{\mathrm{f} / \mathrm{f}}$ mice, and Ms. Yuka Ogata for technical assistance. Metabolic analysis using a Seahorse flux analyzer was performed at the Medical Research Support Center at Kyoto University. This research was supported by the Uehara Memorial Foundation, the Takeda Foundation, the Naito Foundation, the Japan Society for the Promotion of Science (KAKENHI JP25112003 and JP15H01510), and the Japan Science and Technology Agency (PRESTO). R.N.E. was supported by a grant from the National Cancer Institute (National Institutes of Health; RO1 CA57138).

\section{References}

Aoshima K, Baba A, Makino Y, Okada Y. 2013. Establishment of alternative culture method for spermatogonial stem cells using knockout serum replacement. PLoS One 8: e77715.

Asada S, Daitoku H, Matsuzaki H, Saito T, Mukai H, Iwashita S, Kako K, Kishi T, Kasuya Y, Fukamizu A. 2007. Mitogen-activated protein kinase, Erk and p38, phosphorylate and regulate Foxo1. Cell Signal 19: 519-527.

Brinster RL, Zimmermann JW. 1994. Spermatogenesis following male germ-cell transplantation. Proc Nat1 Acad Sci 91: 11298-11302.

ButlerNS, Monick MM, Yarovinsky TO, Powers LS, Hunninghake GW. 2002. Altered IL-4 mRNA stability correlates with Th1 and Th2 bias and susceptibility to hypersensitivity pneumonitis in two inbred strains of mice. J Immunol 169:3700-3709.

Clevers H. 2013. The intestinal crypt, a prototype stem cell compartment. Cell 154: 274-284.

Codega P, Silva-Vargas V, Paul A, Maldonado-Soto AR, Deleo AM, Pastrana E, Doetsch F. 2014. Prospective identification and purification of quiescent adult neural stem cells from their in vivo niche. Neuron 82: 545-559.

de Rooij DG, Russell LD. 2000. All you wanted to know about spermatogonia but were afraid to ask. J Androl 21: 776-798.

Eilers M, Eisenman RN. 2008. Myc's broad reach. Genes Dev 22: 2755-2766.

Gallardo T, Shirley L, John GB, Castrillon DH. 2007. Generation of a germ cell-specific mouse transgenic Cre line, Vasa-Cre. Genesis 45: 413-417.

Gerrits A, Walasek MA, Olthof S, Weersing E, Ritsema M, Zwart E, van Os R, Bystrykh LV, de Harrn G. 2012. Genetic screen identifies microRNA cluster $99 \mathrm{~b} / \mathrm{let}-7 \mathrm{e} / 125 \mathrm{a}$ as a regulator of primitive hematopoietic cells. Blood 119: 377-387.

Goertz MJ, Wu Z, Gallardo TD, Hamra FK, Castrillon DH. 2011. Foxol is required in mouse spermaogonial stem cells for their maintenance and the initiation of spermatogenesis. J Clin Invest 121: 3456-3466.

Hsieh AL, Walton ZE, Altman BJ, Stine ZE, Dang CV. 2015. MYC and metabolism on the path to cancer. Semin Cell Dev Biol 43: 11-21.

Ishii K, Kanatsu-Shinohara M, Shinohara T. 2012. FGF2 mediates mouse spermatogonial stem cell self-renewal via upregulation of Etv5 and Bcl6b through MAP2K1 activation. Development 139: 1734-1743.

Kanatsu-Shinohara M, Shinohara T. 2013. Spermatogonial stem cell self-renewal and development. Annu Rev Cell Dev Biol 29: 163-187.

Kanatsu-Shinohara M, Ogonuki N, Inoue K, Miki H, Ogura A, Toyokuni S, Shinohara T. 2003. Long-term proliferation in 
culture and germline transmission of mouse male germline stem cells. Biol Reprod 69: 612-616.

Kanatsu-Shinohara M, Inoue K, Lee J, Yoshimoto M, Ogonuki N, Miki H, Baba S, Kato T, Kazuki Y, Toyokuni S, et al. 2004. Generation of pluripotent stem cells from neonatal mouse testis. Cell 119: 1001-1012.

Kanatsu-Shinohara M, Inoue K, Miki H, Ogonuki N, Takehashi M, Morimoto T, Ogura A, Shinohara T. 2006. Clonal origin of germ cell colonies after spermatogonial transplantation in mice. Biol Reprod 75: 68-74.

Kanatsu-Shinohara M, Ogonuki N, Miki H, Inoue K, Morimoto H, Takashima S, Ogura A, Shinohara T. 2010. Genetic influences in mouse spermatogonial stem cell self-renewal. I Reprod Dev 56: 145-153.

Kanatsu-Shinohara M, Onoyama I, Nakayama KI, Shinohara T. 2014. Skp1-Cullin-F-box (SCF)-type ubiquitin ligase FBXW7 negatively regulates spermatogonial stem cell self-renewal. Proc Natl Acad Sci 111: 8826-8831.

Kerosuo L, Piltti K, Fox H, Angers-Loustau A, Häyry V, Eilers M, Sariola H, Wartiovaara K. 2008. Myc increases self-renewal in neural progenitor cells through Miz-1. I Cell Sci 121: 3941-3950.

Kim H, Jang H, Kim TW, Kang BH, Lee SE, Jeon YK, Chung DH, Choi J, Shin J, Cho EJ, et al. 2015. Core pluripotency factors directly regulate metabolism in embryonic stem cell to maintain pluriopotency. Stem Cells 33: 2699-2711.

Kimura T, Suzuki A, Fujita Y, Yomogida K, Lomeli H, Asada N, Ikeuchi M, Nagy A, Mak TW, Nakano T. 2003. Conditional loss of PTEN leads to testicular teratoma and enhances embryonic germ cell production. Development 130: 1691-1700.

Knoepfler PS, Cheng PF, Eisenman RN. 2002. N-myc is essential during neurogenesis for the rapid expansion of progenitor cell populations and the inhibition of neuronal differentiation. Genes Dev 16: 2699-2712.

Kubota H, Avarbock MR, Brinster RL. 2004. Growth factors essential for self-renewal and expansion of mouse spermatogonial stem cells. Proc Natl Acad Sci 101: 16489-16494.

Kubota H, Wu X, Goodyear SM, Avarbock MR, Brinster RL. 2011. Glial cell line-derived neurotrophic factor and endothelial cells promote self-renewal of rabbit germ cells with spermatogonial stem cell properties. FASEB J 25: 2604-2614.

Laurenti E, Varnum-Finney B, Wilson A, Ferrero I, Blanco-Bose WE, Ehninger A, Knoepfler PS, Cheng PF, MacDonald HR, Eisenman RN, et al. 2008. Hematopoietic stem cell function and survival depend on c-Myc and N-Myc activity. Cell Stem Cell 3: 611-624.

Laurenti E, Wilson A, Trumpp A. 2009. Myc's other life: stem cells and beyond. Curr Opin Cell Biol 21: 844-854.

Lee J, Kanatsu-Shinohara M, Inoue K, Ogonuki N, Miki H, Toyokuni S, Kimura T, Nakano T, Ogura A, Shinohara T. 2007. Akt mediates self-renewal division of mouse spermatogonial stem cells. Development 134: 1853-1859.

Lee J, Kanatsu-Shinohara M, Morimoto H, Kazuki Y, Takashima S, Oshimura M, Toyokuni S, Shiohara T. 2009. Genetic reconstruction of mouse spermatogonial stem cell self-renewal in vitro by Ras-cyclin D2 activation. Cell Stem Cell 5: 76-86.

Liang Y, Jansen M, Aronow B, Geiger H, van Zant G. 2007. The quantitative trait gene latexin influences the size of the hematopoietic stem cell population in mice. Nat Genet 39: 178-188.

Lin CY, Lovén J, Rahl PB, Paranal RM, Burge CB, Bradner JE, Lee TI, Young RA. 2012. Transcriptional amplification in tumor cells with elevated c-Myc. Cell 151: 56-67.
Maeda I, Okamura D, Tokiake Y, Ikeda M, Kawaguchi H, Mise N, Abe K, Noce T, Okuda A, Matsui Y. 2013. Max is a repressor of germ cell-related gene expression in mouse embryonic stem cells. Nat Commun 4: 1754.

Martello G, Smith A. 2014. The nature of embryonic stem cells. Annu Rev Cell Dev Biol 30: 647-675.

Meistrich ML, van Beek MEAB. 1993. Spermatogonial stem cells. In Cell and molecular biology of the testis (ed. Desjardins C, Ewing LL), pp. 266-295. Oxford University Press, New York.

Morimoto H, Lee J, Tanaka T, Ishii K, Toyokuni S, Kanatsu-Shinohara M, Shinohara T. 2012. In vitro transformation of mouse testis cells by oncogene transfection. Biol Reprod 86: 148.

Muller-Sieburg CE, Riblet R. 1996. Genetic control of the frequency of hematopoietic stem cells in mice: mapping of a candidate locus to chromosome 1. J Exp Med 183: 1141-1150.

Nagano M, Avarbock MR, Brinster RL. 1999. Pattern and kinetics of mouse donor spermatogonial stem cell colonization in recipient testes. Biol Reprod 60: 1429-1436.

Nie Z, Hu G, Wei G, Cui K, Yamane A, Resch W, Wang R, Green DR, Tessarollo L, Casellas R, et al. 2012. c-Myc is a universal amplifier of expressed genes in lymphocytes and embryonic stem cells. Cell 151: 68-79.

Oatley JM, Avarbock MR, Brinster RL. 2007. Glial cell line-derived neurotrophic factor regulation of genes essential for self-renewal of mouse spermatogonial stem cells is dependent on Src family kinase signaling. I Biol Chem 282: 25842 25851.

Ogawa T, Aréchaga JM, Avarbock MR, Brinster RL. 1997. Transplantation of testis germinal cells into mouse seminiferous tubules. Int J Dev Biol 41: 111-122.

Ohtsuka S, Niwa H. 2015. The differential activation of intracellular signaling pathways confers the permissiveness of embryonic stem cell derivation from different mouse strains. Development 142: 431-437.

Paik J-H, Kollipara R, Chu G, Ji H, Xiao Y, Ding Z, Miao L, Tothova Z, Horner JW, Carrasco DR, et al. 2007. FoxOs are lineage-restricted redundant tumor suppressors and regulate endothelial cell homeostasis. Cell 128: 309-323.

Rahl PB, Lin CY, Seila AC, Flynn RA, McCuine S, Burge CB, Sharp PA, Young RA. 2010. c-Myc regulates transcriptional pause release. Cell 141: 432-445.

Rane SG, Dubus P, Mettus RV, Galbreath EJ, Boden G, Reddy EP, Barbacid M. 1999. Loss of Cdk4 expression causes insulin-deficient diabetes and Cdk4 activation results in $\beta$-islet cell hyperplasia. Nat Genet 22: 44-52.

Rato L, Alves MG, Socorro S, Duarte AI, Cavaco JE, Oliveira PF. 2012. Metabolic regulation is important for spermatogenesis. Nat Rev Urol 9: 330-338.

Ray D, Kiyokawa H. 2007. CDC25A levels determine the balance of proliferation and checkpoint response. Cell Cycle 6: 3039-3042.

Schmidt JA, Abramowitz LK, Kubota H, Wu X, Niu Z, Avarbock MR, Tobias JW, Bartolomei MS, Brinster RL. 2011. In vivo and in vitro aging is detrimental to mouse spermatogonial stem cell function. Biol Reprod 84: 698-706.

Scognamiglio R, Cabezas-Wallscheid N, Their MC, Altamura S, Reyes A, Prendergast AM, Baumgartner D, Carnevalli LS, Atzberger A, Haas S, et al. 2016. Myc Depletion induces a pluripotent dormant state mimicking diapause. Cell 164: 668680.

Soucek L, Jucker R, Panacchia L, Ricordy R, Tatò F, Nasi S. 2002. Omomyc, a potential Myc dominant negative, enhances Mycinduced apoptosis. Cancer Res 62: 3507-3510. 
Suzuki A, Hirasaki M, Hishida T, Wu J, Okamura D, Ueda A, Nishimoto M, Nakachi Y, Mizuno Y, Okazaki Y, et al. 2016. Loss of MAX results in meiotic entry in mouse embryonic and germline stem cells. Nat Commun 7: 11056.

Takashima S, Hirose M, Ogonuki N, Ebisuya M, Inoue $\mathrm{K}$, Kanatsu-Shinohara M, Tanaka T, Nishida E, Ogura A, Shinohara T. 2013. Regulation of pluripotency in male germline stem cells by Dmrt1. Genes Dev 27: 1949-1958.

Takehashi M, Kanatsu-Shinohara M, Inoue K, Ogonuki N, Miki H, Toyokuni S, Ogura A, Shinohara T. 2007. Adenovirus-mediated gene delivery into mouse spermatogonial stem cells. Proc Natl Acad Sci 104: 2596-2601.

Takubo K, Nagamatsu G, Kobayashi CI, Nakamura-Ishizu A, Kobayashi H, Ikeda E, Goda N, Rahimi Y, Johnson RS, Soga T, et al. 2013. Regulation of glycolysis by Pdk functions as a metabolic checkpoint for cell cycle quiescence in hematopoietic stem cells. Cell Stem Cell 12: 49-61.
Way A, Knoepfler PS. 2010. c-myc and N-myc promote active stem cell metabolism and cycling as architects of the developing brain. Oncotarget 1: 120-130.

Wilson A, Murphy MJ, Oskarsson T, Kaloulis K, Bettess MD, Oser GM, Pasche A-C, Knabenhans C, MacDonald HR, Trumpp A. 2004. c-Myc controls the balance between hematopoietic stem cell self-renewal and differentiation. Genes Dev 18: 2747-2763.

Wilson A, Laurenti E, Oser G, van der Wath RC, Blanco-Bose W, Jaworski M, Offner S, Dunant CF, Eshkind L, Bockamp E, et al. 2008. Hematopoietic stem cells reversibly switch from dormancy to self-renewal during homeostasis and repair. Cell 135: 1118-1129.

Zhou W, Choi M, Margineantu D, Margaretha L, Hesson J, Cavanaugh C, Blau CA, Horwitz MS, Hockenbery D, Ware C, et al. 2012. HIF $1 a$ induced switch from bivalent to exlusively glycolytic metabolism during ESC-to-EpiSC/hESC transition. EMBO J 31: 2103-2116. 


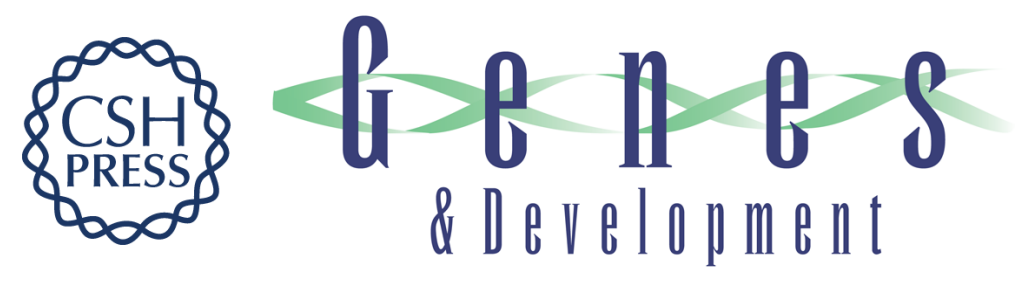

\section{Myc/Mycn-mediated glycolysis enhances mouse spermatogonial stem cell self-renewal}

Mito Kanatsu-Shinohara, Takashi Tanaka, Narumi Ogonuki, et al.

Genes Dev. 2016, 30:

Access the most recent version at doi:10.1101/gad.287045.116

\section{Supplemental http://genesdev.cshlp.org/content/suppl/2016/12/22/30.23.2637.DC1 Material}

References This article cites 56 articles, 19 of which can be accessed free at: http://genesdev.cshlp.org/content/30/23/2637.full.html\#ref-list-1

Creative This article is distributed exclusively by Cold Spring Harbor Laboratory Press for the first Commons six months after the full-issue publication date (see

License http://genesdev.cshlp.org/site/misc/terms.xhtml). After six months, it is available under a Creative Commons License (Attribution-NonCommercial 4.0 International), as described at http://creativecommons.org/licenses/by-nc/4.0/.

Email Alerting Receive free email alerts when new articles cite this article - sign up in the box at the top Service right corner of the article or click here.

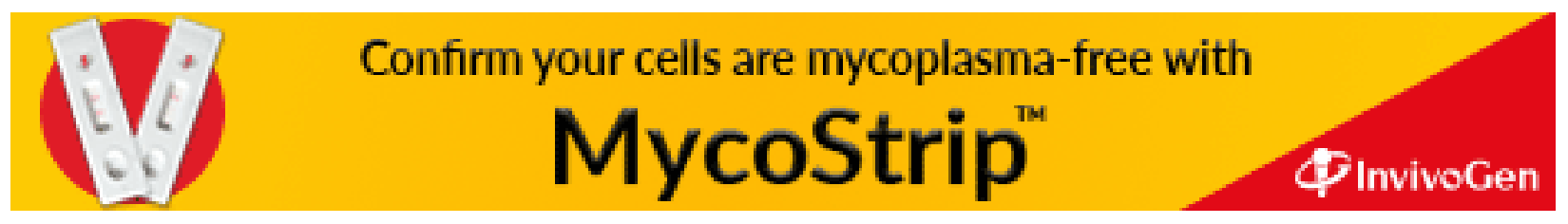

